\title{
Multilayer-exposure maps as a basis for a regional vulnerability assessment for landslides: applied in Waidhofen/Ybbs, Austria
}

\author{
C. Promper ${ }^{1} \cdot$ T. Glade ${ }^{1}$
}

Received: 2 February 2013/ Accepted: 2 March 2015/Published online: 13 April 2016

(C) The Author(s) 2016. This article is published with open access at Springerlink.com

\begin{abstract}
Assessments of natural hazards and risks are beneficial for sustainable planning and natural hazard risk management. On a regional scale, quantitative hazard and risk assessments are data intensive and methods developed are difficult to transfer to other regions and to analyse different periods in a given region. Such transfers could be beneficial regarding factors of global change influencing the patterns of natural hazard and risk. The aim of this study was to show the landslide exposure of different elements at risk in one map, e.g. residential buildings and critical infrastructure, as a solid basis for an in-depth analysis of vulnerability and consequent risk. This enables to overcome the data intensive assessments on a regional scale and highlights the potential hotspots for risk analysis. The study area is located in the alpine foreland in Lower Austria and comprises around $112 \mathrm{~km}^{2}$. The results show the different levels of exposure, as well as how many layers of elements at risk are affected. Several exposure hotspots can be delineated throughout the study area. This allows a decision on in-depth analysis of hotspots not only by indicated locations but also by a rank resulting from the different layers of incorporated elements at risk.
\end{abstract}

Keywords Exposure maps - Vulnerability assessment - Elements at risk · Landslide susceptibility $\cdot$ Waidhofen/Ybbs Austria

\section{Introduction}

The impact of landslides on both assets and human lives is clearly evident in different regions of the world (e.g. Guzzetti 2000; Listo and Carvalho Vieira 2012; Lee and Chi 2011; Zêzere et al. 2008). Every year damages caused by landslides are related to high

\section{T. Glade}

thomas.glade@univie.ac.at

C. Promper

catrin.promper@univie.ac.at

1 Department for Geography and Regional Research, University of Vienna, Universitätsstrasse 1, 1010 Vienna, Austria 
direct and indirect costs for the various parties concerned (Dai et al. 2002; Schuster and Highland 2001; Zêzere et al. 2008). Therefore, the complex issue of landslide risk is an emerging challenge in different parts of the world (Anderson and Holcombe 2013; Corominas et al. 2013; Dai et al. 2002; Glade et al. 2005; Glade 2003a, b; Guzzetti 2000; Martha et al. 2013; Winter and Bromhead 2012). However, besides the analysis of landslide processes, it is important to focus on potential consequences and the respective spatial and temporal changes therein. Therefore, elements at risk and the respective vulnerability need to be taken into account. According to Chambers (2006), vulnerability consists of an external part determining the risks, shocks and stress to which an individual or household is subject to. The internal part relates to the defencelessness which signifies a lack of means to cope without damaging loss (Chambers 2006). This dual structure of vulnerability implies an internal side which can be referred to as the characteristics of an element at risk which also implies coping capacity and an external side which can be translated to natural hazard exposure (see also Fuchs 2009). Therefore, an element at risk, such as a linear structure (e.g. road, electricity line), a local structure (e.g. a bridge, a house) or a spatial structure (e.g. an agricultural field, a forest) can be exposed to a natural hazard due to their spatial location (Fra Paleo 2008) independent of the respective internal vulnerability which is determined by the specific characteristics of the considered object.

Taking a step forward, aspects of global change such as a changed population distribution and land cover conversion influence the spatial and temporal pattern of landslide risk (Gassner et al. 2013). Therefore, the occurrence of natural processes such as landslides is dependent on not only the precipitation changes related to climate change, but also changes in the preparatory factors, e.g. land cover (Glade 2003a; Jemec and Komac 2011; Papathoma-Köhle and Glade 2012). Further changes in land cover influence the spatial distribution of elements at risk. However, not only the location of elements at risk is affected by changes, but also the internal vulnerability due to changing characteristics of the element at risk.

In this chapter, the term "landslide exposure" refers to the exposure of elements at risk towards landslides. Changes in this external spatial component of vulnerability are largely influencing the spatiotemporal pattern of landslide risk. Regarding the anticipated changes mentioned above, the aim of this study focuses on this external side of vulnerability. This represents a first step towards a comprehensive vulnerability analysis as a central part of risk assessment. The results of this study subsequently serve as a solid basis for a detailed vulnerability and hazard analysis in the delineated exposure hotspots and can further be integrated in a comprehensive risk assessment strategy. Further, it should serve as a decision tool on how to rank the different exposure hotspots and apply certain levels of action.

\section{Challenges in regional vulnerability assessments}

The costs related to the occurrence of natural hazards can be generally divided into direct and indirect costs, e.g. physical damage to assets (direct) or traffic disruption (indirect) (Bubeck and Kreibich 2011). These different costs affect various stakeholders, e.g. local community leaders, emergency service personnel, related departments/ministries, professional associations, academic institutions (WEF 2011). Referring to risk mitigation and prevention of the aforementioned costs of natural hazards, one important category is spatial planning/land use management (Frazier et al. 2013; Pfurtscheller et al. 2011; WEF 2011). Spatial planning is an effective tool for future mitigation (Pomaroli et al. 2011) and is 
commonly conducted on a regional scale that also serves balancing political and financial support (Sukarna et al. 2012). Subsequently, stakeholders and decision makers need detailed data on potential risks and herein damage potential for respective cost/benefit judgements and the related mitigation planning on a regional scale. Therefore, the overall aim of a quantitative risk assessment is to provide the degree of loss or costs per unit area, both direct and indirect, respectively (Hufschmidt et al. 2005; Sterlacchini et al. 2007; Varnes 1984). A quantitative risk assessment on this detailed level incorporates many different datasets on elements at risk, e.g. data on building type, number of inhabitants or details on critical infrastructure (Corominas et al. 2013; van Westen et al. 2008). The results of these assessments need to be provided on a highly precise level also related to vulnerability (Hufschmidt and Glade 2010). Therefore, it is important to serve the need for a regional assessment as a first step towards the identification of locations where in-depth analysis is required; Kappes et al. (2012) refer to such a procedure as top-down approach. The subsequent results of the detailed analysis then indicate the potential loss and these may be traded off against protection costs, a classical procedure within cost/benefit analysis (FEMA 1997; Fuchs 2013). This is also referred to in various studies dealing with exposure to different hazards, e.g. Løvholt et al. (2012) on tsunami exposure, Kappes et al. (2012) on multihazards or Pellicani et al. (2013) on landslides.

In this chapter, landslide risk is understood as a function of physical vulnerability of different sets of elements at risk, their potential damage and a frequency and magnitude relation of landslide processes, thus the landslide hazard (Varnes 1984). Therefore, it is an interaction of vulnerability including the exposure and hazard (Birkmann et al. 2013; Fuchs et al. 2013a; Keiler et al. 2006; Bell and Glade 2004; Lee and Jones 2004, to name a few studies only).

Related to the aforementioned need for quantitative assessments, the applied definition for physical vulnerability is associated with "the degree of loss to a given element, or set of elements, within the area affected by a hazard and it is expressed on a scale of 0 (no loss) to 1 (total loss)" (Fuchs et al. 2013b; Glade et al. 2005; Papathoma-Köhle et al. 2012; Pitilakis et al. 2011; Totschnig et al. 2011; Varnes 1984; UNDRO 1984). Focusing on physical vulnerability assessments, several studies show how intense these data requirements are (e.g. Birkmann et al. 2013; Papathoma-Köhle et al. 2011; van Westen et al. 2008). As an example of physical vulnerability assessment, engineers focus in particular on the individual behaviours of structures such as buildings, bridges, roads towards the impact of a natural process (Papathoma-Köhle et al. 2011; Pitilakis et al. 2011). This leads to the demand of specific process-related data such as pressure, velocity, depth and of detailed data on the construction type of the building and its characteristics.

Related to spatiotemporal changes exposure is changing on a different time scale than internal vulnerability. The change in exposure is mostly related to new development areas or increased susceptibility to a natural hazard in a location of existing elements at risk. In contrast, internal vulnerability varies with changes in, e.g. standards of living (Fra Paleo 2008) which is based on individual, local basis and therefore can change more quickly. The assessment of the landslide exposure can serve as a first indicator where detailed analysis on internal vulnerability and hazard aspects is needed. These can also be referred to as landslide exposure hotspots.

The method applied in this study is trying to account for the spatial changes since the spatial and temporal dimensions are very important within any integrated disaster risk management (Aubrecht et al. 2013). Therefore, the suggested and applied method is not trying to reflect the perfect local site conditions; it rather serves as a flexible concept in which a minimum number of two datasets can be extended to an infinite number of 
available datasets. In this study, multiple layers of elements at risk are assessed and analysed in order to define the aforementioned exposure hotspots. The focus is clearly on the built environment and their physical vulnerability (Papathoma-Köhle et al. 2011). However, the method also allows a connection to the affected population via the building use.

The main objective of this study is to apply a method for a regional multilayer-exposure assessment of elements at risk that can be transferred in space (to other regions), and with exchange of input data also a transfer in time is conceivable. The results will show how many types of building assets and streets are potentially affected by landslides in a specific location on the regional scale and indicate where additional in-depth analysis is necessary. In the following paragraphs, the applied method is explained in detail, and the study area is introduced. Then the analysis of the obtained results is presented, and a discussion concludes this chapter.

\section{Data preparation and methods}

The analysis is based on the exposure concept presented above and is technically implemented by the overlay of a set of elements at risk and a landslide susceptibility map (Glade et al. 2012; Kappes et al. 2012; Pellicani et al. 2013). As delineated above, a susceptibility map for this analysis is adequate because it is conducted on a regional scale and provides general information on the spatial probability of landslide occurrence. In this chapter, we decided to delineate the different datasets before explaining the method applied because the knowledge on the various datasets facilitates the comprehensibility of the method section.

\subsection{Data}

Three sets of elements at risk are integrated in the exposure analysis: (1) selected critical infrastructure, (2) roads and streets and (3) residential buildings and schools. These sets refer to buildings of critical infrastructure, e.g. fire brigades, transformers, etc. (1) to infrastructure related to e.g. road blockages (2) and to buildings where the presence of people is highly likely (3). This approach is similar to the concept of Papathoma-Köhle et al. (2007), wherein the building type determines respective types of vulnerability assessed. For example, "human" vulnerability is calculated by multiplying residents with the vulnerability of the building.

For the generation of the vector datasets, the basic data (e.g. street network; digital cadastral map) were provided by the Provincial Government of Lower Austria. The road and street network and the buildings were extracted from the provided datasets and complemented by orthophotograph mapping and field work. In Table 1, all established datasets used for this analysis are listed and briefly characterized.

These process-related data can be related to either a landslide hazard or a susceptibility map. Herein, the susceptibility map presents the potential location of landslides based on various terrain factors. The hazard map includes information about temporal probability and intensity based on a frequency/magnitude relationship (e.g. Glade et al. 2005; Guzzetti et al. 1999; Lee et al. 2004). The intensity represents the localized impact of the landslide event and the characteristic of the landslide mass that can be locally variable (Corominas and Mavrouli 2011). This additional information leads to the possibility of the application 
of, e.g. vulnerability functions where detailed information on the process intensity is needed. However, for regional assessments landslide susceptibility maps are an adequate tool to approximate potentially endangered areas.

\subsection{Methodological approach}

In the following, the preparation of layers of elements at risk and the subsequent analysis is explained in detail. Details on the calculation of the applied landslide susceptibility map are provided in Gassner et al. (2014) and Promper et al. (2015). As the presented analysis requires detailed information on the elements at risk, it was necessary to design and implement a building database.

The building database is based on a vector data layer where all buildings in the study area are defined as polygons. Given the ID of each polygon, this database was complemented during field work by the type of building ( 27 categories), the number of storeys (max. 5 stories) and a visual inspection of the condition of the buildings (classified in three conditions). If necessary, an additional description on any particular features was recorded. In the data analysis, all 27 codes assigned to buildings were regrouped to eight categories (see Table 2). This simplification was required because the analysis of 27 categories would not give a clear overview on the composition of the different building types. However, the additional codes serve to extract the dataset on critical infrastructure from the building database for the exposure analysis.

The example in italics indicates a building which is a residential building with two storeys in an overall good condition. For assigning the condition of the building criteria such as intact roof, façade and windows were adduced. The description of the example (highlighted as italics in Table 2) indicates that the building is renovated at the moment; therefore, the condition "good" was already assigned. Regarding the type of buildings "Residential and Business", all buildings with business and one or two floors of residence are included. The category "Adjacent Buildings" comprises more or less garages or sheds related to residential buildings. Additionally, also stables and sheds as Adjacent Buildings to farms are included in the group "Adjacent Buildings" (farms). The category "Other" refers to buildings that did not match any other category. The total number of these specific buildings, e.g. buildings related to critical infrastructure like the fire department, is very low. These building functions are then indicated in the description field of the respective building (Table 2).

For the preparation of the multiple layers of elements at risk, the first step was to extract the different types of elements at risk, e.g. buildings of critical infrastructure, and to

Table 1 Established datasets used in this analysis (including examples, refer to text)

\begin{tabular}{lll}
\hline Dataset ID & Description & Type \\
\hline Build_code & Buildings & Vector (polygon) \\
Stre_code & Roads and streets & Vector (line) \\
EaR_1 & Residential and school buildings extracted from build_code & Raster (20 m) \\
EaR_2 & Buildings representing critical infrastructure extracted from build_code & Raster (20 m) \\
EaR_3 & Street rasterized from stre_code & Raster (20 m) \\
Sc_Ls & Landslide susceptibility map (Source: Gassner 2013) & Raster (20 m) \\
\hline
\end{tabular}


Table 2 Building categories

\begin{tabular}{lllll}
\hline Categories & Type & Storeys & Condition & Description \\
\hline 1 & Residential building & 1 & Bad & Optional \\
2 & Adjacent Buildings (residential) & 2 & Moderate & Optional \\
3 & Farm & 3 & Good & In renovation \\
4 & Adjacent Buildings (farm) & 4 & & Optional \\
5 & Residential and business & 5 & & Optional \\
6 & Business & & & Optional \\
7 & Schools & & & Optional \\
8 & Other & & Optional \\
\hline
\end{tabular}

Eight regrouped categories a building can be assigned (please refer to text below for the example in italics)

enlarge them by a buffer of $50 \mathrm{~m}$. This buffer represents the average length of landslides in the study area and is applied to account for the whole area of a landslide. Therefore, it represents a minimum distance from the landslide scarps to the potential impact on an element at risk. This buffer distance is calculated by the square root of the average area of all landslides occurred in Waidhofen/Ybbs and recorded within the building ground register (BGR-provided by the Provincial Government of Lower Austria). It serves as approximation of the range of a landslide potentially impacting various elements at risk. In a second step, these layers of the different types of elements at risk including the buffer area were prepared as binary raster files with 0 (element at risk not present) and 1 (element at risk including buffer present) for each type of element at risk.

This leads to the raster set EaR_1 (see Table 1) which indicates all schools and residential buildings. For the second dataset EaR_2, all buildings related to critical infrastructure were extracted of the category "Other" and rasterized. The third layer EaR_3 represents the roads and streets. The results are three binary files containing pixels with 1 for either the respective building or street including the $50 \mathrm{~m}$ buffer and 0 for the rest of the data layer (see also Fig. 1).

The susceptibility map was calculated by statistical logistic regression modelling (Atkinson and Massari 1998; Bell 2007; Van Den Eeckhaut et al. 2006) with a random sample $(n=606)$ having slides and non-slides equally distributed (Gassner et al. 2014). The statistical modelling of input parameters was conducted in $R$ using stepwise backward variable selection, based on Akaike's information criterion (Akaike 1974). For the validation, the area under the ROC is used as a criterion [refer to Gassner et al. (2014) and Promper et al. (2015) for details]. For visualization and comparability, classification is conducted by equal interval to obtain four classes.

The principle aim is to overlay the layers of elements at risk with the landslide susceptibility in order to define where and how many layers of elements at risk are affected by, e.g. high landslide susceptibility. For traceability of the four overlayed datasets, it is important to define a code consisting of four digits. This is achieved by multiplying the first layer (susceptibility) by 1000, the second (EaR_1) by 100, the third (EaR_2) by 10 and the fourth (EaR_3) by 1 with a raster calculator in a GIS environment (see Fig. 1). The four values are summed for a final code consisting of four digits.

The final four-digit code represents the result of the multilayer-exposure map. Consequently, each pixel is assigned this code expressing the value for landslide susceptibility 


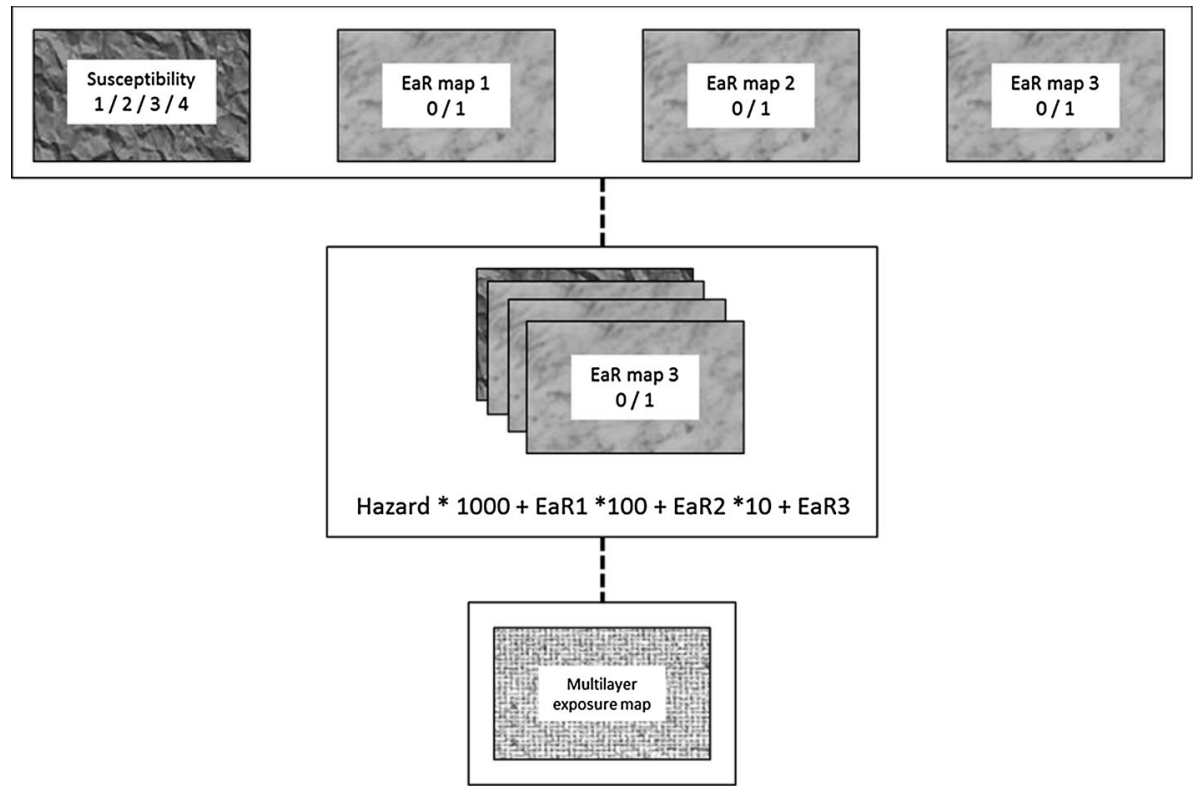

Fig. 1 Procedure of intersecting the process and elements at risk datasets

Table 3 Possible codes of intersection results

\begin{tabular}{|c|c|c|c|c|c|c|c|c|}
\hline \multirow{2}{*}{$\begin{array}{l}\text { Affected } \\
\text { susceptibility }\end{array}$} & \multicolumn{8}{|c|}{ EaR layer } \\
\hline & $\begin{array}{l}\text { No } \\
\text { EaR }\end{array}$ & EaR_3 & EaR_2 & EaR_1 & $\begin{array}{l}\text { EaR_3 } \\
\text { and } \\
\text { EaR_2 }\end{array}$ & $\begin{array}{l}\text { EaR_1 } \\
\text { and } \\
\text { EaR_1 }\end{array}$ & $\begin{array}{l}\text { EaR_1 } \\
\text { and } \\
\text { EaR_3 }\end{array}$ & $\begin{array}{l}\text { EaR_1 and } \\
\text { EaR_2 and } \\
\text { EaR_3 }\end{array}$ \\
\hline 1 & 1000 & 1001 & 1010 & 1100 & 1011 & 1110 & 1101 & 1111 \\
\hline 2 & 2000 & 2001 & 2010 & 2100 & 2011 & 2110 & 2101 & 2111 \\
\hline 3 & 3000 & 3001 & 3010 & 3100 & 3011 & 3110 & 1301 & 3111 \\
\hline 4 & 4000 & 4001 & 4010 & 4100 & 4011 & 4110 & 4101 & 4111 \\
\hline
\end{tabular}

and the respective elements at risk (Fig. 1). The possible combinations of the generated codes are listed in Table 3.

It needs to be emphasized that the codes do not represent numbers, but an order of digits describing the exposure of the relevant elements at risk, e.g. 4011, means that the layers EaR_2 and EaR_3 are cumulated in this specific location and are highly exposed because of the landslide susceptibility class 4 . Further, it can be delineated that a building related to critical infrastructure as well as a street is located in this specific spot which is highly susceptible to landslides.

The illustration of these 32 possible combinations (Table 3) in one map would not give a distinct overview on the regional scale and it would not be possible to delineate clearly the landslide exposure hotspots. Therefore, only the three layers of the elements at risk are cumulated in a first step using the same procedure as described above. This allows the calculation of a single map on how many layers of elements at risk are present in one 
location (Fig. 2a). Thereafter this aggregated layer is multiplied with the susceptibility map (Fig. 2b). This leads to a reduction from 32 to 12 classes (see legend Fig. 2c) which is acceptable as a first approximation. However, in the database the codes are still available, and it is easy to detect which layers of elements at risk are affected in the area of interest. Furthermore, it is also possible to search specific codes, for example, that show all pixels in high susceptibility level where EaR_1 and EaR_2 are affected (code = 4110). Therefore, the resulting map enables a fast approximation to identify exposure hotspots including the possibility of accessing quickly details on locations of interest.

\subsection{Study area}

The district Waidhofen/Ybbs is located in the alpine foreland in Lower Austria (Fig. 3). The region comprises approximately $112 \mathrm{~km}^{2}$ and covers the lithological units of Flysch in the northern part and calcareous rocks in the southern part (Wessely 2006). The dominating land cover classes are grassland in the northern part of the study area and forest in the southern part. There is a high activity of landslides throughout the study area with many different types including slides, flows and complex landslides (Petschko et al. 2010). These occur on natural slopes and artificial slope cuts. The impact of landslides in this area often causes damages on roads and on buildings (Fig. 4a, b; Pomaroli et al. 2011).

Approximately 11,500 people are living in the study area giving a population density of about 90 inhabitants per $\mathrm{km}^{2}$. The distribution of the building area is twofold. Firstly, buildings are concentrated along the flat valleys, and secondly, scattered hamlets and farm houses can be found throughout the hilly region. Typical buildings are shown in Fig. 4c, d. Partially these scattered farm houses are difficult to reach by unpaved streets. The city Waidhofen/Ybbs serves as a regional centre where basic infrastructure such as schools and emergency services is provided (Pomaroli et al. 2011).

\section{Results}

\subsection{Building database}

The building database comprises in total more than 4400 buildings. More than $80 \%$ of the buildings in the study area have 1-2 storeys, and approximately $90 \%$ are in good condition. In Fig. 5, all building types are grouped in eight categories showing the percentage on the total number of buildings. It clearly indicates the high number of 2150 residential
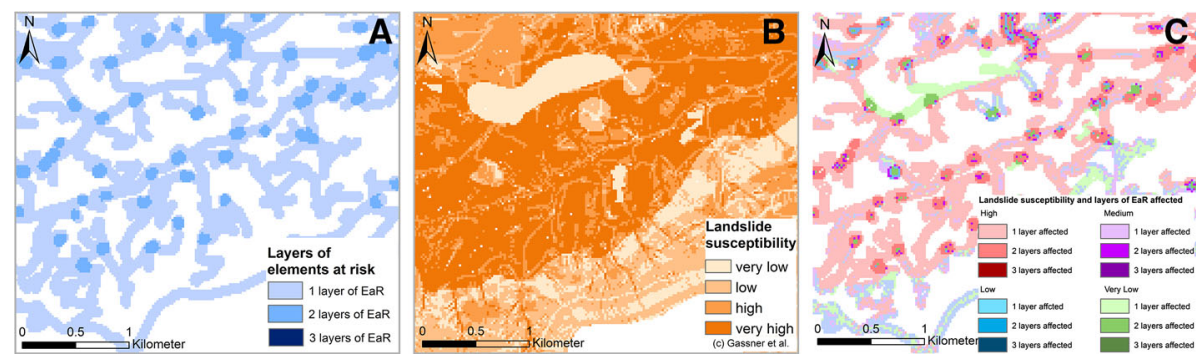

Fig. 2 Schematic presentation of the method displayed in maps including a the number of layers of elements at risk, $\mathbf{b}$ the landslide susceptibility map and $\mathbf{c}$ the final combined map 


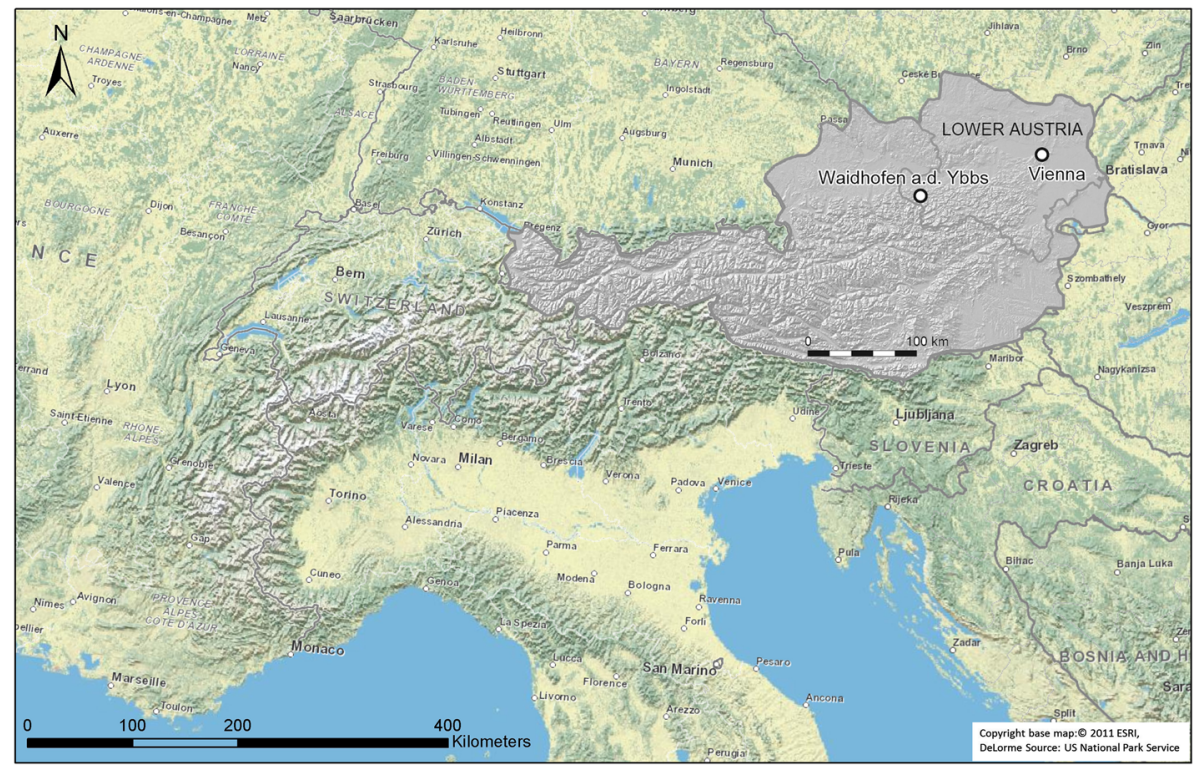

Fig. 3 Location of study area "Waidhofen/Ybbs" in Austria
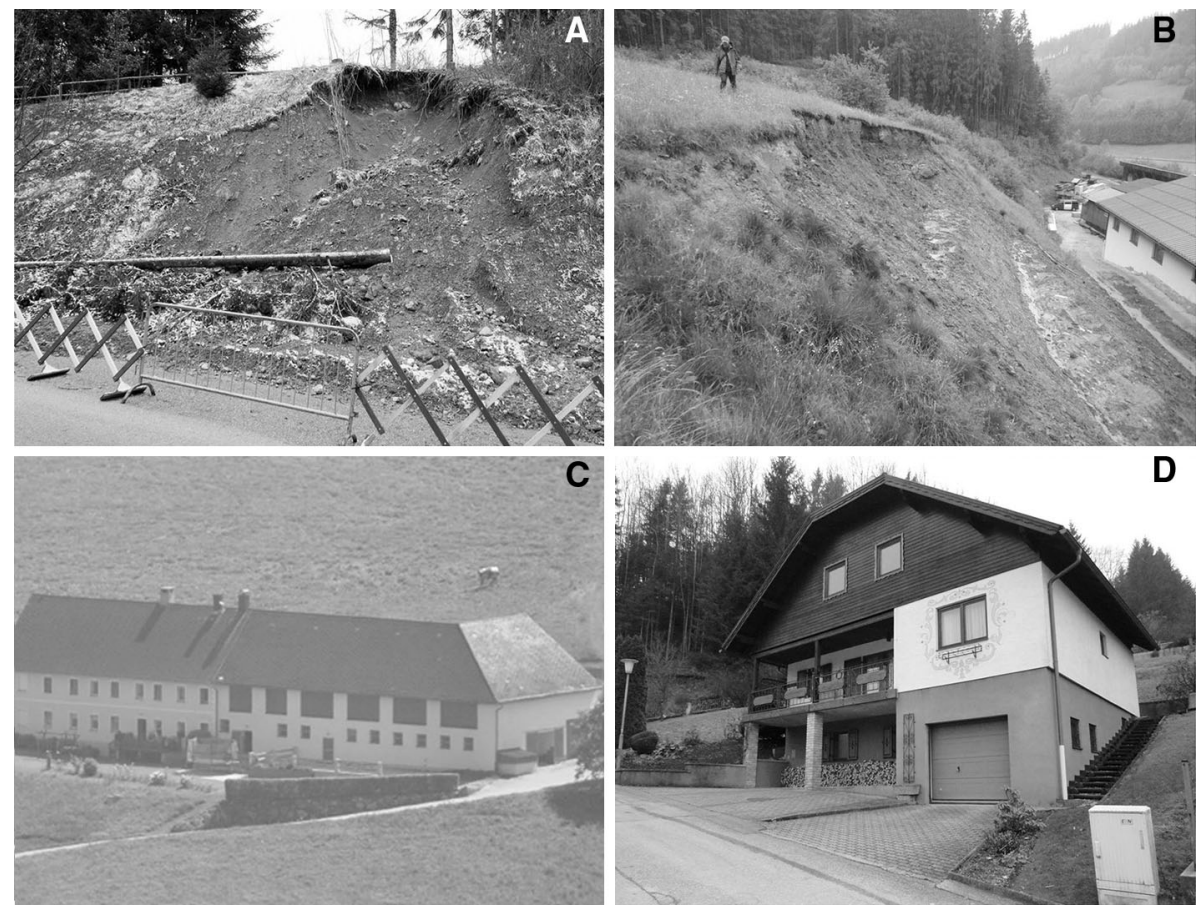

Fig. 4 Landslides affecting a street and a building in Waidhofen/Ybbs (a, b), typical farm house and a typical single family house (c, d) (pictures taken by: a Canli 2013, b, d Gokesch 2014, c Langmann/Zwirner 2011) 
buildings followed by the "Adjacent Buildings". About 754 Adjacent Buildings such as sheds and stables can be found at the 225 farms. Thus, each farm has one or more Adjacent Building. Overall, the total number of residential buildings including farms and the combination of residential and business covers more than $50 \%$ of all buildings.

The general distribution of the buildings in the study area is displayed in Fig. 6. The spatial analysis shows that especially buildings related to critical infrastructure are concentrated in the centre of the study area, in particular near Waidhofen/Ybbs. This relates to the high number of inhabitants and the respective requirements on the critical infrastructures e.g. water, energy or emergency units. Furthermore, the concentration of the residential buildings in the valley bottoms, the scattered settlements and the farmhouses on the hilltops are obvious. Topographical factors in combination with centralized access to infrastructure and services can be factors influencing this distribution.

\subsection{Multilayer-exposure map}

The colours of the spatial analysis of the multilayer-exposure map (Fig. 7) indicate that areas with high and medium landslide susceptibility are located in the Northern part, whereas areas with lower susceptibility can be found in the south of the study area. However, in the south-western region are also spots of high susceptible areas. The mapping of the landslides in the study of Petschko et al. (2010), based on ALS, indicates fewer but larger landslides in the southern part of the study area, probably following the lithology.

Combining this landslide susceptibility map with the different layers of elements at risk the hotspots of exposure of respective elements at risk towards a given landslide susceptibility can be directly delineated. In particular alongside the valleys in the west of the city, the respective exposure hotspots are located, whereas in the east of the city of Waidhofen/ Ybbs, locations with multiple layers of elements at risk are only affected by low or medium landslide susceptibility. Additionally, certain locations in the southern area show susceptible regions coinciding with various layers of elements at risk; therefore, further hotspots of exposure can be allocated.

Regarding the northern part of the study area, several locations of multiple layers of elements at risk can be found, especially in medium and high susceptible landslide areas. The city of Waidhofen/Ybbs itself provides a lot of different elements at risk; however, all are located in flat areas and, therefore, only in the lowest landslide susceptibility class. The results clearly indicate that also in sparsely populated areas multiple layers may be exposed to different landslide susceptibilities and thus need attention by the respective stakeholder.

In Fig. 7, a section of the study area is presented. This section has been selected because it demonstrates the various classes of the multilayer-exposure map eloquently. The

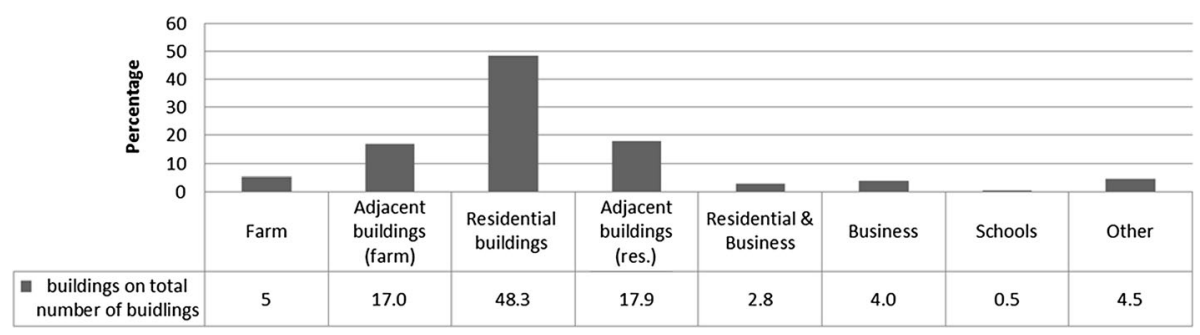

Fig. 5 Percentage of different buildings types on total number of buildings in study area 


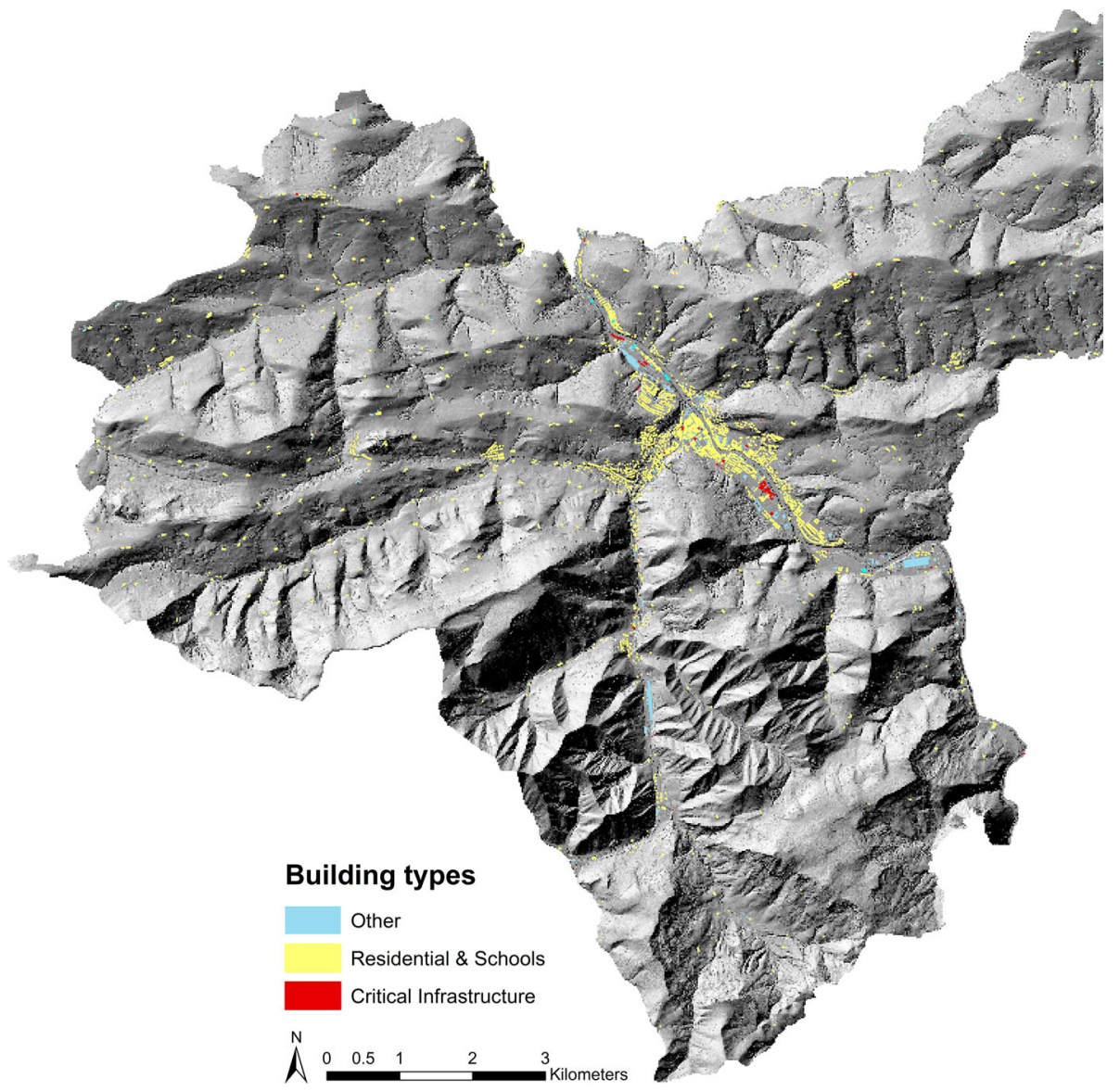

Fig. 6 Distribution of the different elements at risk layers in Waidhofen/Ybbs (DEM provided by the provincial government of Lower Austria Note: there is no aerial photograph of the top right corner; therefore, this had to be excluded in the further analysis)

figure identifies that although located in a region where landslide susceptibility is generally rather low, there are hotspots where many layers of elements at risk can be found in areas of high landslide susceptibility. A detailed view on the section indicates large areas where only one layer is located in the high landslide susceptibility class. However, upslope next to the road there are locations where e.g. besides street area also building area or a layer of critical infrastructure is superimposed by high susceptibility.

\section{Discussion and conclusion}

\subsection{Building database}

The results from the analysis of the building database enable a good overview on the general compound of the different building types and the overall condition of the buildings 


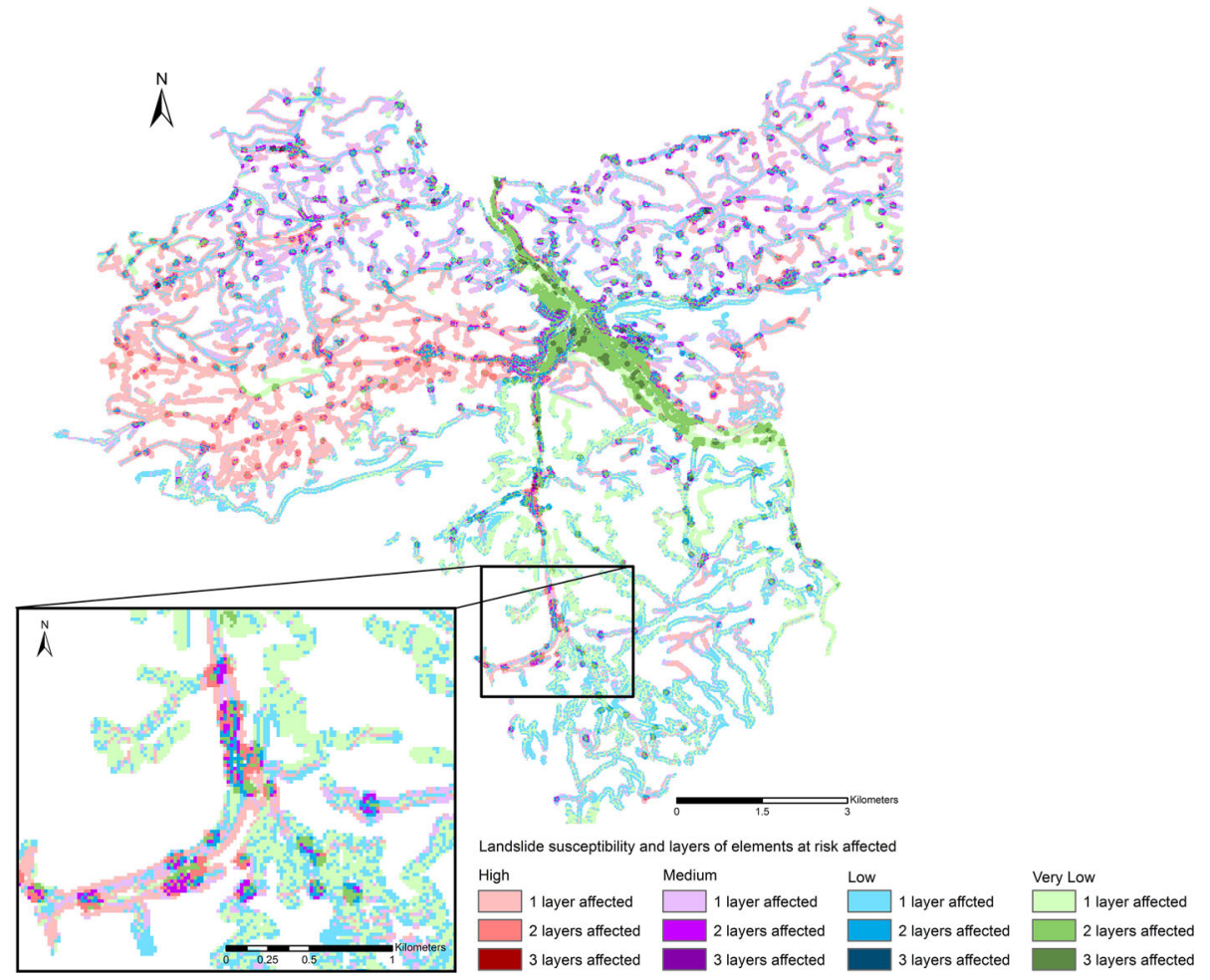

Fig. 7 Multilayer-exposure map of Waidhofen/Ybbs (including the layers, critical infrastructure (buildings), roads and streets and residential buildings and schools) and a detailed section

in the study area. This enables to detecting immediately where people e.g. residents in houses or children at schools can be potentially affected by a landslide impact. This is also possible for buildings related to critical infrastructure (e.g. power transformer), which is important not only regarding responses after an impact but also with respect to disaster risk management planning. In the meantime, one has to bear in mind the associated uncertainty based on the visual allocation of the building type. Not necessarily, all buildings are the visually allocated building type. Nevertheless, specific buildings of a certain type appear similar or have clear indication on the respective usage, and therefore, it is assumed that the respective epistemic uncertainty is very low. Additionally, all buildings in one class are treated equally in this study e.g. a building related to an emergency service is classified equally to a transformer.

\subsection{Multilayer-exposure map}

The results enable to distinguish landslide exposure hotspots of buildings and streets, respectively. Especially the highly exposed areas can be delineated by visual interpretation on a regional scale. Thus, the applied method meets the basic requirements for assessing landslide exposure hotspots and shows distinctively where further investigation on vulnerability and risk is needed. However, looking at the map depicting the whole study area, the overview appears cluttered and in some locations multiple exposure hotspots may be 
overseen. Further, it is difficult to distinguish between the medium levels of exposure. This relates to the fine pixel size that was selected for this study. This can be encountered by e.g. upscaling the map. This would give a better overview and enable an even faster assessment of where more detailed analysis is necessary. On the other hand upscaling could imply missing smaller hotspots.

Using the multilayer-exposure map as an interactive map provides an additional feature which makes it possible delineating which types of elements at risk are affected in a certain location in a short time by analysing the underlying code of the multilayer exposure. Another feature could also be e.g. selecting all areas where critical infrastructure and residential buildings as well as schools are affected. Using this additional information, it is also possible to make a ranking of measures by assessing efficiently which elements at risk are affected in the aforementioned hotspots. These results can serve as a basis to delineate where which vulnerability assessments need to be carried out for the respective types of elements at risk. An example would be to define hotspots and immediately derive that a vulnerability assessment is not only needed for buildings but also for population.

As for the spatial transferability, this method does not require a large amount of data; however, a spatial distribution of landslide susceptibility is required. Regarding the elements at risk, a primary dataset of buildings or streets can be mapped by aerial photograph interpretation or field work. Moreover, the temporal transferability can be conducted by incorporating updated datasets referring to elements at risk or also the landslide process.

\subsection{Uncertainties}

When applying the results of this study, one has to be aware of the associated uncertainties. This results from input data, as well as from the modelling procedures. Firstly the susceptibility map, based on logistic regression, contains uncertainties. Further, the applied buffer of $50 \mathrm{~m}$ surrounding the elements at risk is based on an average assumption related to occurred and reported landslides. However, the real and future landslide areas may vary significantly. Further this is afflicted with the assumption that the damage to an element at risk is the same throughout the landslide. This is in contrast to other findings, e.g. by Fell et al. (2008) who reported higher damage on the boundaries or scarps when analysing large landslides. However, this assumption had to be taken due to missing alternatives, but significant improvements are indeed possible. The underestimation of this buffer distance or also an overestimation due to the modelled susceptibility data can influence the results of this study in either way. Referring to the elements at risk, the conversion of polygonal data into raster data adds additional uncertainty. This increases the inaccuracy of the location of the elements at risk; however, for the regional assessment this uncertainty is acceptable because the datasets are not analysed on precise divisions, e.g. on the plot level. Despite the knowledge of these uncertainties, it was not possible to address these in the current analysis, but nevertheless, these need to be stated clearly.

\subsection{Advantages and disadvantages}

The overall aim of the study of applying a simple method enabling an easy transferability in space and time of the exposure assessment can be regarded as accomplished. The results show the landslide exposure hotspots of the different sets of elements at risk. This overlay of several elements at risk, in a further step, enables the potential user to assess which elements are specifically affected in a particular location. Especially regarding spatial planning, the transferability into the future of this method is important because social and 
economic losses due to landslide processes can be reduced by effective planning (Greiving and Angingnard 2014; Pomaroli et al. 2011) and management (Dai et al. 2002; Fra Paelo 2008). Another option for further analysis is to add other data such as population distribution that improves the usability of the method in landslide risk management, but also disaster risk management.

The advantages of this method include the possibility of adding changed datasets quickly; thus, a new output with updated datasets can be generated with an adequate amount of resources. For example, if new land cover scenarios are available, this method can be used to analyse future scenarios such as analysing the exposure of future building areas. Another asset is the possibility of rating the different exposure hotspots according to either the relevant layer or the number of layers of elements at risk affected. For instance, a hotspot where all three layers of elements at risk are affected by high landslide susceptibility can be analysed in depth before the analysis of two layers located in an area of medium susceptibility. Providing this map on an interactive basis enables further to distinguish quickly how many types of elements at risk are affected in a certain location or vice versa where e.g. a particular number of elements at risk is affected. This is advantageous when taking different types of vulnerability into account. Although the target of this study is physical vulnerability, it is possible to connect it to social vulnerability (similar to Papathoma-Köhle et al. 2007) by extracting a layer of buildings of, e.g. hospitals, primary schools, etc., from the database as a first indication where high vulnerable population groups are exposed. Referring herein to economic vulnerability, it is also possible to extract buildings related to business and therein analyse where potential business interruption can be expected in case of a landslide event. In a second step, the related internal vulnerability of these assets needs to be analysed.

The disadvantages of this method are clearly that, despite of the detailed results that are provided on a regional scale, these cannot be illustrated efficiently on the respective level. Therefore, a ranking of hotspots is not possible on visual interpretation but only by consulting an interactive map. Further, the assumption that all buildings in one group are of the same importance when, for example, talking about critical infrastructure is problematic.

Concluding this method provides a sound and efficient method to illustrate how many layers of elements at risk are affected by a potential landslide impact in a certain location. Depending on the selected elements at risk (in this study case the building type), this can be the basis for the assessment of different vulnerability types and in a further step landslide risk assessment. The method enables to consider spatial changes over time of the landslide exposure and, however, does not consider internal vulnerability factors like coping capacity.

Acknowledgement This study is carried out within the FP7 ERA-NET project ChangingRISKS (Grant agreement number 263953). The authors thank the European Union for funding this project. The authors also thank the Provincial Government of Lower Austria for their support and the provision of data.

Open Access This article is distributed under the terms of the Creative Commons Attribution 4.0 International License (http://creativecommons.org/licenses/by/4.0/), which permits unrestricted use, distribution, and reproduction in any medium, provided you give appropriate credit to the original author(s) and the source, provide a link to the Creative Commons license, and indicate if changes were made.

\section{References}

Akaike H (1974) A new look at the statistical model identification. IEEE Trans Autom Control 19:716-723 
Anderson MG, Holcombe E (2013) Community-based landslide risk reduction managing disasters in small steps. World Bank, Washington DC

Atkinson PM, Massari R (1998) Generalized linear modelling of suceptibility to landsliding in the Central Apennines, Italy. Comput Geosci 24:373-385

Aubrecht C, Fuchs S, Neuhold C (2013) Spatio-temporal aspects and dimensions in integrated disaster risk management. Nat Hazards 68:1205-1216. doi:10.1007/s11069-013-0619-9

Bell R (2007) Lokale und regionale Gefahren- und Risikoanalyse gravitativer Massenbewegungen an der Schwäbischen Alb (dissertation), Universität Bonn

Bell R, Glade T (2004) Quantitative risk analysis for landslides? Examples from Bíldudalur NW-Iceland. Nat Hazards Earth Syst Sci. 4:117-131. doi:10.5194/nhess-4-117-2004

Birkmann J, Cardona OD, Carreño ML, Barbat AH, Pelling M, Schneiderbauer S, Kienberger S, Keiler M, Alexander D, Zeil P, Welle T (2013) Framing vulnerability, risk and societal responses: the MOVE framework. Nat Hazards 67:193-211. doi:10.1007/s11069-013-0558-5

Bubeck P, Kreibich H (2011) CONHAZ costs of natural hazards WP 1 final report: natural hazards: direct costs and losses due to the disruption of production process WP 1 final report

Chambers R (2006) Vulnerability, coping and policy (editorial introduction). IDS Bull 37:33-40. doi:10. 1111/j.1759-5436.2006.tb00284.x

Corominas J, Mavrouli O (2011) Guidelines for landslide susceptibility, hazard and risk assessment and zoning. SafeLand deliverable 2.4

Corominas J, Westen C, Frattini P, Cascini L, Malet JP, Fotopoulou S, Catani F, Eeckhaut M, Mavrouli O, Agliardi F, Pitilakis K, Winter MG, Pastor M, Ferlisi S, Tofani V, Hervás J, Smith JT (2013) Recommendations for the quantitative analysis of landslide risk. Bull Eng Geol Environ 73:209-263. doi:10.1007/s10064-013-0538-8

Dai FC, Lee CF, Ngai YY (2002) Landslide risk assessment and management: an overview. Eng Geol 64:65-87

Fell R, Corominas J, Bonnard C, Cascini L, Leroi E, Savage WZ (2008) Guidelines for landslide susceptibility, hazard and risk zoning for land use planning. Eng Geol 102:85-98

FEMA (1997) Report on costs and benefits of natural hazard mitigation. Washington DC

Fra Paleo U (2008) On exposure to natural hazards: revisiting a neglected primal action. In: Fra Paelo U (ed) NATO advanced research workshop on spatial planning as a strategy for migration and adaptation to natural hazards. IOS Press, Santiago de Compostela 1-34

Frazier TG, Walker MH, Kumari A, Thompson CM (2013) Opportunities and constraints to hazard mitigation planning. Appl Geogra 40:52-60. doi:10.1016/j.apgeog.2013.01.008

Fuchs S (2009) Mountain hazards, vulnerability, and risk-a contribution to applied research on humanenvironment interaction. Habilitationsschrift, Universität Innsbruck

Fuchs S (2013) Cost-benefit analysis of natural hazard mitigation. In: Bobrowsky P (ed) Encyclopedia of natural hazards. Encyclopedia of Earth Sciences Series. Springer, Dordrecht, pp 121-125

Fuchs S, Keiler M, Sokratov S, Shnyparkov A (2013a) Spatiotemporal dynamics: the need for an innovative approach in mountain hazard risk management. Nat Hazards 68:1217-1241. doi:10.1007/s11069-0120508-7

Fuchs S, Keiler M, Tsao T-C (2013b) Magnitude and frequency: challenges for the assessment of vulnerability to geomorphic hazards. In: Brebbia CA (ed) Risk analysis VIII. WIT Press, Southampton

Gassner C, Promper C, Petschko H, Glade T (2013) Scenarios of future landslide susceptibility-incorporating changes in land cover and climate. European Geoscience Union General Assembly 2013. Copernicus Publications, Vienna

Gassner C, Promper C, Beguería S, Glade T (2014) Climate change impact for spatial landslide susceptibility IAEG XII Congress engeneering geology for soiety and territory. Springer, Torino, pp 429_433

Glade T (2003a) Landslide occurrence as a response to land use change: a review of evidence from New Zealand. Catena 51:297-314

Glade T (2003b) Vulnerability assessment in landslide risk analysis. Erde 134:128-139

Glade T, Anderson MG, Crozier MJ (2005) Landslide hazard and risk. Wiley, Chichester 807

Glade T, Kappes MS, Frigerio S, Malet JP (2012) Multi-hazard exposure analyses with multirisk-a platform for user-friendly analysis. 12th Congress INTERPRAEVENT, Grenoble, France, pp 487-495

Greiving S, Angignard M (2014) Disaster mitigation by spatial planning. In: Van Asch T, Corominas J, Greiving S, Malet J-P, Sterlacchini S (eds) Mountain risks: from prediction to management and governance. Springer, Netherlands. Advances in natural and technological hazards research, pp 287-302

Guzzetti F (2000) Landslide fatalities and the evaluation of landslide risk in Italy. Eng Geol 58:89-107 
Guzzetti F, Carrara A, Cardinali M, Reichenbach P (1999) Landslide hazard evaluation: a review of current techniques and their application in a multi-scale study, Central Italy. Geomorphology 31:181-216. doi:10.1016/S0169-555X(99)00078-1

Hufschmidt G, Glade T (2010) Vulnerability analysis in geomorphic risk assessment. In: Alcántara-Ayala I, Goudie A (eds) Geomorphological hazards and disaster prevention. Cambridge University Press, Cambridge, pp 233-243

Hufschmidt G, Crozier MJ, Glade T (2005) Evolution of natural risk: research framework and perspectives. Nat Hazards Earth Syst Sci 5:375-387

Jemec M \& Komac M (2011) An overview of approaches for hazard assessment of slope mass movements.In: Alpine mass movements: implications for hazard assessment and mapping, special edition of journal torrent, avalanche, landslide and rock fall engeneering

Kappes MS, Gruber K, Frigerio S, Bell R, Keiler M, Glade T (2012) The multirisk platform: the technical concept and application of a regional-scale multihazard exposure analysis tool. Geomorphology 151-152:139-155. doi:10.1016/j.geomorph.2012.01.024

Keiler M, Sailer R, Jörg P, Weber C, Fuchs S, Zischg A, Sauermoser S (2006) Avalanche risk assessmenta multi-temporal approach, results from Galtür. Austria Nat Hazards Earth Syst Sci 6:637-651. doi:10. 5194/nhess-6-637-2006

Lee Y-F, Chi Y-Y (2011) Rainfall-induced landslide risk at Lushan. Taiwan Eng Geol 123:113-121. doi:10. 1016/j.enggeo.2011.03.006

Lee EM, Jones DKC (2004) Landslide risk assessment. Thomas Telford, London

Listo FDLR, Vieira BC (2012) Mapping of risk and susceptibility of shallow-landslide in the city of São Paulo, Brazil. Geomorphology 169-170:30-44. doi:10.1016/j.geomorph.2012.01.010

Løvholt F, Glimsdal S, Harbitz CB, Zamora N, Nadim F, Peduzzi P, Dao H, Smebye H (2012) Tsunami hazard and exposure on the global scale. Earth Sci Rev 110:58-73. doi:10.1016/j.earscirev.2011.10. 002

Martha TR, van Westen CJ, Kerle N, Jetten V, Vinod Kumar K (2013) Landslide hazard and risk assessment using semi-automatically created landslide inventories. Geomorphology 184:139-150. doi:10.1016/j. geomorph.2012.12.001

Papathoma-Köhle M, Glade T (2012) The role of vegetation cover change for landslide hazard and risk. In: Renaud G, Sudmeier-Rieux K, Estrella M (eds) The role of ecosystems in disaster risk reduction. UNU Press, Tokyo, pp 293-320

Papathoma-Köhle M, Neuhäuser B, Ratzinger K, Wenzel H, Dominey-Howes D (2007) Elements at risk as a framework for assessing the vulnerability of communities to landslides. Nat Hazards Earth Syst Sci 7:765-779

Papathoma-Köhle M, Kappes M, Keiler M, Glade T (2011) Physical vulnerability assessment for alpine hazards: state of the art and future needs. Nat Hazards 58:645-680. doi:10.1007/s11069-010-9632-4

Papathoma-Köhle M, Keiler M, Totschnig R, Glade T (2012) Improvement of vulnerability curves using data from extreme events: debris flow event in South Tyrol. Nat Hazards 64:2083-2105. doi:10.1007/ s11069-012-0105-9

Pellicani R, Van Westen C, Spilotro G (2013) Assessing landslide exposure in areas with limited landslide information. Landslides 11:463-480. doi:10.1007/s10346-013-0386-4

Petschko H, Glade T, Bell R, Schweigl J, Pomaroli G (2010) Landslide inventories for regional early warning systems. In: Malet J-P, Glade T, Casagli N (eds) Mountain risks: bringing science to society. CERG, Firenze, pp 277-282

Pfurtscheller C, Locher B, Thieken AH (2011) CONHAZ Costs of natural hazards WP 8 final report: costs of alpine hazards

Pitilakis K, Fotopoulou S, Argyroudis S, Pitilakis D, Senetakis K, Treulopoulos K, Kakderi K, Riga E (2011) Physical vulnerability of elements at risk to landslides: methodology for evaluation, fragility curves and damage states for buildings and lifelines. SafeLand deliverable 2.5

Pomaroli G, Bell R, Glade T, Heiss G, Leopold P, Petschko H, Proske H, Schweigl J (2011) Darstellung der Gefährdung durch gravitative Massenbewegungen im Bundesland Niederösterreich als Grundlage der Raumplanung. Gefahrendarstellungen für Massenbewegungen. Wildbach- und Lawinenverbau, Zeitschrift für Wildbach-, Lawinen-, Erosions- und Steinschlagschutz 74:198-206

Promper C, Gassner C, Glade T (2015) Spatiotemporal patterns of landslide exposure - a step within future landslide risk analysis on a regional scale applied in Waidhofen/Ybbs Austria. Int J Disaster Risk Reduct 12:25-33. doi:10.1016/j.ijdrr.2014.11.003

Schuster RL \& Highland LM (2001) Socioeconomic and environmental impacts of landslides in the western hemisphere. U.S. Geological Survey Open-File Report 01-0276

Sukarna D, Wirakusumah AD, Suhaemi IA, Eka S, Surono, Soedradjat, GM, Solihin A, Hendrasto M, Abdurachman KE, Andreastuti MCSD, Danaryanto H, Murdohardono D, Sugalang, Wafid M, 
Herudiyanto, Mulyasari F, Kastuari A, Adar S, Tissahadi IK, Jaeger S, Hoffmann-Rothe A, Pischke B, Ranke U \& Weiland L (2012) Guidebook for assessing the risks to natural hazards case study: Province of Central Java

Sterlacchini S, Frigerio S, Giacomelli P, Brambilla M (2007) Landslide risk analysis: a multi-disciplinary methodological approach. Nat Hazard Earth Syst Sci 7:657-675

Totschnig R, Sedlacek W, Fuchs S (2011) A quantitative vulnerability function for fluvial sediment transport. Nat Hazards 58:681-703. doi:10.1007/s11069-010-9623-5

UNDRO (1984) Disaster prevention and mitigation-a compendium of current knowledge, vol 11. Preparedness Aspects, New York

Van Den Eeckhaut M, Vanwalleghem T, Poesen J, Govers G, Verstraeten G, Vandekerckhove L (2006) Prediction of landslide susceptibility using rare events logistic regression: a case-study in the Flemish Ardennes (Belgium). Geomorphology 76:392-410

van Westen CJ, Castellanos E, Kuriakose SL (2008) Spatial data for landslide susceptibility, hazard, and vulnerability assessment: an overview. Eng Geol 102:112-131

Varnes DJ (1984) Landslides hazard zonation: a review of principles and practice. UNESCO, Paris

WEF (2011) A vision for managing natural disaster risk-proposals for public/private stakeholder solutions

Wessely G (2006) Geologie der österreichischen Bundesländer-Niederösterreich. Geologische Bundesanstalt, Wien

Winter M, Bromhead E (2012) Landslide risk: some issues that determine societal acceptance. Nat Hazards 62:169-187. doi:10.1007/s11069-011-9987-1

Zêzere JL, Garcia RAC, Oliveira SC, Reis E (2008) Probabilistic landslide risk analysis considering direct costs in the area north of Lisbon (Portugal). Geomorphology 94:467-495. doi:10.1016/j.geomorph. 2006.10.040 